\title{
Learning and inclusivity via Interactive Groups in Early Childhood Education and Care in the Hope School, Spain
}

\begin{abstract}
Access to high-quality early childhood education and care (ECEC), particularly for disadvantaged children, is critical to ensuring that future learning is more effective and more likely to continue throughout life. A wealth of research has provided extensive information about the key factors that impact the quality of ECEC and improve cognitive and social outcomes. Despite the European priority to make high-quality ECEC available to all children, accomplishing this goal remains a challenge. The present article discusses a specific type of inclusive classroom organisation called Interactive Groups (IGs). IGs were studied in the preschool classrooms of an urban school located in a disadvantaged area of Spain that has high levels of unemployment, poverty and marginalisation. Empirical data from interviews with teachers, daily life stories from mothers and children, and classroom observations shed light on the perceptions of the potential of this particular classroom setting, where children are placed in small, mixed-ability groups coordinated by one volunteer from the community, to benefit children and promote their cognitive, social and emotional development. The findings suggest that this particular form of inclusive classroom organisation can reach children from a minority background while providing high-quality ECEC.
\end{abstract}

Keywords: Interactive Groups, Early Childhood Education, Successful Educational Actions, Early Classroom Leaving.

\section{INTRODUCTION}

School failure is a problem that OECD countries are addressing - through policies that are designed to reduce failures and improve equity in education-because reducing school failure can be a key factor in social development and economic growth (OECD, 2012). Educational research has demonstrated that if solid foundations are laid in the early years, later learning is more effective and more likely to continue throughout life (Cunha, Heckman, Lochner, \& Masterov, 2005; Elffers, 2012). Therefore, education is a powerful tool during the very early stages of life, particularly if quality early childhood education is provided to all students (OECD, 2012). Several studies (Belfield \& Levin, 2007) indicate that investment in ECEC is even more beneficial for socially disadvantaged children including migrants, ethnic minorities and those living in poverty. It helps to close the achievement gap and reduce the costs to society of lost talent and public spending on social, health and justice systems (Levin, 2009; Wößmann \& Schüetz, 2006). In particular, Roma children would benefit from high-quality ECEC, as it constitutes one of the five models of intervention for achieving inclusive education established by the Roma Education Fund (2015). Therefore, the key role of high-quality early childhood education and care (ECEC) programmes in reducing school failure is particularly important for disadvantaged children, for whom the vicious cycle of failure and exclusion is repeated from one generation to the next (García, Girbés, \& Gómez, 2015).

The recommendations of the European Commission (2011a; 2011b) to the Member States about early childhood education and care build on this evidence. There seems to be a consensus regarding the importance of increasing children's access to ECEC, but the most relevant point of agreement is that 'access is not enough'; rather, it is quality that can actually make a difference. Interventions in the early years that provide such high-quality education are those, 
which aim to achieve efficiency and equity for all. In particular, this concept suggests that ECEC should be "designed and delivered to meet all children's full range of needs, cognitive, emotional, social and physical" (European Commission, 2011a, p. 6). In this context, evaluating the quality of ECEC is increasingly important and educational research can contribute to determining which programmes boost and sustain children's achievement outcomes over time (Ishimine \& Tayler, 2014).

In seeking to identify the classroom interventions that may provide high-quality ECEC and make ECEC available to all children, this article draws on the analysis of one Successful Educational Action. Successful Educational Actions (SEAs) were analysed by the INCLUDED Project ${ }^{1}$, which aimed to identify practices that address the issues of school failure and student dropout in Europe. These actions are founded on dialogic learning and, based on this concept, they have been successful in engaging families and communities in school spaces (Flecha, 2015). Using the communicative methodology of research (Gómez, Puigvert, \& Flecha, 2011), these successful actions were identified by analysing 27 case studies of successful schools that serve families with low socioeconomic status and migrant or minority backgrounds across the European Union (Elboj, 2015).

SEAs are not merely good practices that have shown good results in specific contexts; rather they have led to the best results in many diverse contexts, achieving positive progress both academically and socially, without additional resources, by using existing resources in the school and the community more efficiently. Essential to SEAs is the scientific evidence on which they are built and that results in two fundamental characteristics that differentiates them from any other school practice. SEAs are universal and transferable to different contexts that achieve increased academic performance and improved social relations at school. Interactive Groups (IGs) are one of the SEAs identified by the INCLUD-ED project and are characterised by two main features: 1) the organisation of students into heterogeneous groups and 2) the reorganisation of human resources to manage student diversity within shared learning environments (Flecha, 2015). IGs are based on the idea that it is important to enrich the communicative processes in learning environments by increasing and diversifying learning interactions. To accomplish this, heterogeneous groups of pupils are created and a volunteer adult is assigned to each group to encourage peer interaction around the learning activity (García, Girbés \& Gómez, 2015).

The present article focuses on an exploration of IGs in the preschool classrooms of children aged 3, 4 and 5 in Hope school in Spain, and analyses the potential of IGs to improve education for minority groups. The school selected for this study is an example of a school which experienced an important process of transformation - from a ghetto to a magnet school — and which has improved both academic achievement and social cohesion (Díez-Palomar, SantosPitanga, \& Álvarez-Cifuentes, 2013). Flecha and Soler (2013) outline some demographic details about Hope school and its social context: the school is located in a very deprived area of the Spanish city of Albacete, where residents face hard living conditions and have high rates of unemployment. Ninety percent of the population in the neighbourhood is Roma and almost $50 \%$ of them have had only basic education. The rate of illiteracy among adults is

${ }^{1}$ INCLUD-ED. Strategies for Inclusion and Social Cohesion in Europe from Education (European Commission, FP6, 2006-2011. Grant agreement: 028603) is the only research in the SSH that was selected by the European Commission as one of its 10 success stories in research that have an added value for society. Retrieved on October $2^{\text {nd }} 2015$ from http://europa.eu/rapid/press-release_MEMO-11-520_en.htm 
approximately $25 \%$. Hope school used to serve children from minority backgrounds, most of them Roma, from ages 3 to 12 (i.e., preschool and primary education) until they started offering secondary education in 2008. Before 2006, when the school was transformed into a learning community, the educational context was one of school failure, with $36 \%$ of students not achieving minimum academic standards and truancy rates of 74\% (Díez-Palomar, SantosPitanga, \& Álvarez-Cifuentes, 2013). Furthermore, the neighbourhood is geographically marginalised by a highway that separates it from the rest of the city. Social marginalisation is also strong and the population living there includes vulnerable groups such as ethnic minorities - primarily Roma - and immigrant populations that live in poverty and suffer from unemployment, low educational levels (Flecha \& Soler, 2013) and deprived health conditions largely due to poverty (Brown, Gómez, \& Munté, 2013). The Roma population is one of the most disadvantaged minority groups in Spain and beyond, and the challenges that Roma children encounter in the educational system are considerable (OECD, 2012). However, in Hope some of these challenges are perceived as being tackled.

The present article is divided into four main sections. First, contextual research on the contributions of high-quality ECEC is presented. Second, the methodology used to conduct the case study is described, followed by the data analysis and the implementation of IGs in ECEC in Hope school. Then, the results are presented detailing the perception of the research participants of positive outcomes by IGs on the academic performance of the children in ECEC at Hope school as well as on children's social and emotional development. To conclude the article, the main ideas of the results are discussed.

\section{RELEVANCE OF HIGH-QUALITY ECEC}

Education during the early years provides the best opportunity for investment in human capital due to its impact on later opportunities during schooling at the primary and secondary levels (Cunha, Heckman, Lochner, \& Masterov, 2005). Many researchers in different countries have shown the positive impact of ECEC not only for children but also for their families and society as a whole (OECD, 2011; Flecha, Soler, \& Sordé, 2015). However, these benefits depend upon the quality of the education and care that children receive from an early age. According to research, children benefit more when educational curricula in early years are focused on social and emotional development as well as on the development of academic skills (Rhoades, Warren, Domitrovich, \& Greenberg, 2011; Stipek, 2006). In particular, several studies have examined the mechanisms by which children's social-emotional skills are associated with later academic success (Denham, Bassett, Mincic, Kalb, Way, Wyatt, \& Segal, 2012; Hall, Sylva, Sammons, Melhuish, Siraj-Blatchford, \& Taggart, 2013; Stipek, 2006; Welsh, Parke, Widaman, \& O'neil, 2001). Some of these studies have analysed successful ECEC programmes, especially for disadvantaged children. Overall, there is consensus for curricula that create a rich and stimulating learning environment in ECEC, which is critical for a highquality education in early childhood. By addressing social development and competencies in math, reading and writing at the same time, the curricula contribute to reduced disparities between children from more privileged social environments and those from more deprived backgrounds (Graves, 2011; Ladd, 2012).

In these curricula, the importance placed on learning aspects such as reading and mathematics is noteworthy (Graves, 2011; Zigler, Gilliam, \& Jones, 2006). Developing school readiness in mathematics and reading has a strong positive relationship with maths scores obtained in elementary and middle school, especially for students from minority backgrounds (Bodovsky 
\& Youn, 2012). Teachers can encourage children's engagement in learning and task-focused behaviour in their early years, before formal education starts, in a very stimulating and joyful learning environment (Sairanen \& Kumpulainen, 2014). Furthermore, teachers can create learning environments where all students can feel successful and experience a sense of achievement. This means that teachers acknowledge children's individual differences and needs and provide appropriate tasks and activities to help them move beyond their zone of proximal development (Pakarinen, Kiuru, Lerkkanen, Poikkeus, Ahonen, \& Nurmi, 2011). Vygotsky (1978) developed this concept, which describes the important role that adults can play in helping children develop their existing abilities so that the children can improve their capacity for solving problems by themselves. Adults' cultural knowledge can contribute to children's development and adults can help children improve their learning by participating in schools.

In most countries of the European Union, early childhood education is focused on ensuring the quality of the ECEC curriculum. To boost the benefits of ECEC, the Quality Toolbox for Early Childhood Education and Care (OECD, 2011) established five policy levers ${ }^{2}$ which each individual country should address when deciding how to tackle this issue. These policy levers are primarily focused on quality: the improvement of teacher training, the design of new curriculum, the engagement of families and communities and the importance of evidence-based action. Thus, the policy orientation is clearly directed to the quality of ECEC rather than to educational access from an early age. Taguma, Litjens and Makowiecki (2012) noted a comparison between American and European researchers, stating that while European scholars are most likely to support non-cognitive learning areas, researchers in the United States tend to support an academic ECEC approach. Despite the policy implemented by each country, multiple analyses agree on the need for more research focused on disseminating alternative and evidence-based curriculum models which have already been adapted and successfully implemented in specific places.

\subsection{Interactions for successful cognitive, social and emotional development}

Interactions play a key role in the quality of learning and social behaviour in the school context; in this regard, research has found that the quality of dialogue and interactions in the classroom is essential to creating a rich learning environment (Engevik, Hølland, \& Hagtvet, 2015; García-Carrión \& Villardón-Gallego, 2016; Howe \& Abedin, 2013; Meacham, 2016; Mercer, 2008). The interactions and everyday relationships that are established in educational spaces are particularly critical in schools that are located in disadvantaged urban areas and that serve pupils with minority backgrounds, including immigrants and Roma, among others (García, Girbés \& Gómez, 2015). Grounded in socio-cultural theory, these studies describe the importance of interactions among peers, and between students and many diverse adults, in addition to teachers (Carr, Barned, \& Otumfuor, 2016). We find the basis of this premise in Vygotsky's works (1978, p. 86), in which the relevance of adult guidance for learning and development is established: "the level of potential development as determined through problem solving under adult guidance, or in collaboration with more capable peers" highlighting especially the importance for the development of the myriad abilities children are learning and

\footnotetext{
${ }^{2}$ Policy Lever 1: Setting out quality goals and regulations; Policy Lever 2: Designing and implementing curriculum and standards; Policy Lever 3: Improving qualifications, training and working conditions; Policy Lever 4: Engaging families and communities; Policy Lever 5: Advancing data collection, research and monitoring. Retrieved from http://www.oecd.org/education/school/startingstrongiiiaqualitytoolboxforecec.htm
} 
developing. While children engage in a learning process, the adult guidance will enhance the developmental process. Later research has indicated that the role of adults (mainly parents) in facilitating children's development by impacting children's zone of proximal development is unique and cannot be replaced by more capable peers (Radziszewska \& Rogoff, 1991). An important body of literature focuses on the impact of adult-child interactions on children's cognitive and non-cognitive development, indicating the relationship between the richness of interactions and stimulus and better or worse development (Cooper, 2010; Fram, Kim, \& Sinha, 2012; Galindo \& Sheldon, 2012; Huntsinger \& Jose, 2009).

Some studies have demonstrated that encouraging high-quality language interactions at the preschool level is very important for children with language difficulties, especially for those from disadvantaged situations (Piasta, Justice, Cabell, Wiggins, Turnbull, \& Curenton, 2012; Bae, 2009). Other research has found that the quality of ECEC depends on the type and quality of interactions that children have with diverse adults such as professionals, relatives and other community members (Urban, Vandenbroeck, Van Laere, Lazzari, \& Peeters, 2012), mainly because those communicative interactions are crucial to acquiring functional skills (Popp \& Wilcox, 2012). Yet the benefits extend beyond language gains. The quality of interactions at an early age and the relationship of those interactions with children's well-being and emotional development has also been studied by Whitebread (2012), who provides evidence-based resources and methodological tools, especially for practitioners, to implement an excellent practice in early childhood classrooms. Similarly, research on the role of peer interactions and friendships has shown that these activities foster positive feelings in children which help them to be happier at school and perform better in school-related tasks (Hartup, 1996). In addition, these interactions have the power to strengthen children's acquisition of social skills, which can later help them to manage their social relationships effectively and achieve better coexistence (Danby, Thompson, Theobald, \& Thorpe, 2012).

Emphasising the effects of high-quality ECEC, Bennett (2011) defends an integrated curriculum in which cognitive and social development are elements of equal importance. Having a strong curriculum contributes to reducing the need for special education, increasing class quality and providing better transitions to primary school (Eurydice, 2009). Highlighting the benefits of interactions for all children in an analysis of pupil participation in northern Norway, Bae (2009) emphasises the importance of encouraging children to participate and express themselves in different types of school interactions. Studying two cases of everyday situations in class, he found that children from minority backgrounds also benefitted from participating in dialogic interactions, through which they improved their communication and friendship opportunities.

If interactions with adults and peers constitute critical experiences for children's learning and development, it is also vital to create environments that are rich in terms of interactions that lead children towards higher levels of development. Consequently, family and community involvement in ECEC is a core issue for children's development (Cooper, 2010; Garcia-Yeste, Redondo-Sama, Padrós, \& Melgar, 2016; Urban, Vandenbroeck, Van Laere, Lazzari, \& Peeters, 2012). Recent studies have indicated that the involvement of family and community members in children's learning spaces in schools has a positive influence on academic achievement (Abenavoli, Greenberg \& Bierman, 2015; Flecha, 2015; Galindo \& Sheldon, 2012; Morlà Folch, 2015). When family members participate in classrooms to help children with their school learning, the number of educative interactions between children and adults increases and learning is accelerated (Gatt, Ojala, \& Soler, 2011). 
2.2. Inclusive classroom organisation vs. ability grouping at very early ages: the case of Interactive Groups

In spite of the existing evidence that segregating children by ability does not increase educational attainment (Boaler, Wiliam, \& Brown, 2000; Braddock \& Slavin, 1992; Chorzempa \& Graham, 2006; Hallam, Ireson, \& Davies, 2004; Ireson, Hallam, \& Hurley, 2005; OECD, 2012), structured ability grouping of very young children seems to be on the rise. In some European countries such as England, this is performed even among 5-year-olds and primarily in literacy and mathematics, where children are put into different classrooms or in groups inside and across classrooms according to their perceived abilities (Hallam \& Parson, 2013). Children living in environments with high levels of deprivation and those who are from minority backgrounds attain less in school when early educational segregation is practised, and in these cases social segregation tends to be higher (Sammons, Sylva, Melhuish, SirajBlatchford, Taggart, \& Grabbe, 2007). The earlier this type of segregation takes place, the greater are the inequalities created among the students, and the more likely students are to leave school early in the future (Flecha, 2015; OECD, 2012).

Building on the theoretical contributions of the importance of quality interactions, especially in ECEC, Interactive Groups (IGs) not only offer an alternative to segregation by ability groups but also offer the possibility of increasing and diversifying interactions between children from an early age. This method of classroom organisation creates an inclusive learning environment by distributing students in small heterogeneous (in terms of gender, ability, ethnicity, etc.) groups of 5 or 6 students within the same classroom. This classroom organisation also has other positive effects, as for instance, it tackles the gap between different learning environments at home, in preschool or in primary education (Hedegaard, 2014). The school further leverages the human resources that are already present in the community by placing adults in each of the groups and thereby increasing interactions among peers and between peers and adults. Adults such as parents or other family and community members enter the classroom as volunteers and are distributed over the different groups (one adult per group). They do not need to have a high academic level because their main role is not to solve tasks, but to promote learning interactions among the students in each IG so that the students can find a solution to the activity by themselves and with the help of others within a limited time. The role of the volunteer is to encourage the child who knows the answer to explain how to solve the task. This interaction not only benefits those who are helped, but the child who explains can also consolidate his or her knowledge and learn different strategies and skills while helping someone else. For this reason, the role of the adult is essential to guaranteeing quality peer interactions and mutual support to succeed in the task, but does not include making a particular subject-knowledge contribution. (Valls \& Kyriakides, 2013)

Once each group finishes the first activity, the groups rotate and change activities (usually spending approximately 20 minutes for each activity). In this type of classroom organisation, all students perform all of the activities that have been previously planned by the teacher for one session: there are as many activities as there are Interactive Groups (normally four or five), primarily focused on instrumental learning.

Language and interaction play an important role in the process, and interacting with different adults from different backgrounds gives the children an opportunity to encounter different ways to use language, different cultural codes and different strategies or skills. The community participation of volunteers constitutes an irreplaceable component in the implementation of IGs. For instance, having a mother from a Muslim country volunteering in class gives students 
the chance to indirectly learn specific traditions from that culture, as well as to know and to respect it. Within this dynamic, the work that all the teachers, children and volunteers do together is important to increasing interactions and accelerating the learning process.

Research has tested IGs in primary education prior to studying their use with ECEC populations and has demonstrated that this form of classroom organisation increases expectations for the students' success among teachers, families and students and that these high expectations contribute to strengthening the learning process, improving the learning environment and coexistence, and increasing the learning outcomes of all children involved (Valls \& Kyriakides, 2013).

Considering the significance of the early years of education later in children's development (Wößmann \& Schüetz, 2006), the fact of putting into practice the already mentioned elements that an inclusive classroom organisation involves-i.e., heterogeneous grouping, peer interaction, reallocation of resources including family and community members and promoting instrumental learning-becomes crucial. Along these lines, our analysis is oriented by the overarching research question: Can Interactive Groups, when used in ECEC as well as in a disadvantaged area (such as the area where Hope school is located) help prevent what has been called early classroom leaving ${ }^{3}$ ? This concept defines the process of segregating children, especially those from vulnerable groups such as ethnic minorities or migrants, at the very early stages of schooling into groups that present low expectations for educational attainment. In order to respond to this research question we enquired, first, how IGs develop, if any, a rich and stimulating learning environment that promotes a cognitive development. Second, we attempt to find out whether it promotes a positive social and emotional development among young children. The article, thus, focuses on enquiring the potential that IGs have to create a learning environment that enhances interactions among peers and between peers and adults, and which avoids initiating a process that segregates children by background or ability.

\section{METHODS}

The communicative methodology used in this analysis (Gómez, Puigvert, \& Flecha, 2011) has been acknowledged by the European Commission to be especially appropriate for research with vulnerable groups and for having "significant social and political impact on the European educational and social systems" (European Commission, 2010). The communicative methodology of research is aimed at social transformation; therefore, it not only describes a reality but also analyses how the reality can be improved (Schulz, 2016) and which specific actions have to be implemented to improve the living conditions of a particular community (Padrós, 2014). This methodology builds on a wealth of theoretical contributions from the social sciences analysing the dialogic turn in our societies and emphasising the role of dialogue in most of the social processes and especially in social change (Beck, 1992; Elster, 1998; Giddens, 1991; Habermas, 1987). For this purpose, an intersubjective dialogue between researchers and the research participants is established and based on egalitarian dialogue. During fieldwork the researcher has the responsibility to contribute with the scientific knowledge while the stakeholders bring in the context-specific knowledge. Connecting the lifeworld of the people and the scientific knowledge provided by the researcher, they jointly analyse and interpret the reality that is under investigation. The power relations between the

\footnotetext{
3 The concept early classroom leaving was coined and first used by Ramon Flecha. Retrieved from http://amieedu.org/debate/index.php?topic $=130.0$
} 
researcher and the people being subject of research are minimised in this dialogue, as both contributions are crucial for the progress of the analysis of the problems. (Gómez, Puigvert, \& Flecha, 2011).

The results presented in this article are from a case study conducted as part of the EU-funded INCLUD-ED Project. Although funding for this project ended in December 2011, the agreement with the European Commission includes an extension for dissemination and knowledge transference which enabled us to conduct this case study in one of the participating schools, Hope school, with a specific focus on ECEC. Therefore, in May 2013 the fieldwork for this case study was conducted in three classrooms with children who were 3, 4 and 5 years of age. Before Hope implemented Successful Educational Actions, conflicts, absenteeism and early school leaving were routine (Flecha $\&$ Soler, 2013). After implementing SEAs, academic performance significantly improved. This can be seen in the student enrolment, which had decreased to less than one third over the decade from 1994-1995 (334 students) to 2005-2006 (100 students) but was being recovered since the reopening of the school in 2006 and finally led to a total of 236 students in 2012-2013. Because students in the neighbourhood were no longer failing or dropping out, but rather wanted to continue their studies, the school began to offer secondary education in 2008 (Girbés-Peco, Macías-Aranda, \& Álvarez-Cifuentes, 2015). IGs were first implemented in ECEC classrooms in 2010, and the results of this practice have not been analysed thus far. Consequently, the successful evolution of the school and of the academic performance of the students in primary education, as well as the positive trend towards overcoming the persistent social exclusion of the neighbourhood, made this school an appropriate candidate for a case study of the implementation and impact of IGs in ECEC.

\subsection{Data collection techniques}

To achieve the purpose of this study three qualitative data collection techniques were used: communicative in-depth interviews, communicative daily-life stories and communicative observations. All three techniques are embedded in the communicative methodology and, thus, incorporate the previously mentioned features such as egalitarian dialogue between the researcher and the research participants. The research participants are an active agent in the research and it is the responsibility of the researcher to make this very clear in the beginning of either technique used (Gómez, Puigvert, \& Flecha, 2011). In the present study the three communicative in-depth interviews were carried out with teachers of the 3,4 and 5-year-old children's classes. Their perspective of the potential of IGs in ECEC is discussed with them as teachers, interpreting the reality of this classroom organisation and its outcomes jointly and contrasting it with the scientific evidence pointing at venues for preventing early classroom leaving by promoting the cognitive and positive social and emotional development.

Six communicative daily-life stories with mothers and children were conducted with the purpose to jointly reflect on their reality and consider specific aspects from the past or present that are related to the classroom organisation, academic performance and social and emotional well-being to assess the implementation of IG in ECEC. In these reflections the focus is set on any aspect related to IG also future expectations that arise through this new reality, rather than on the biographical description of the research participants' lives.

Lastly, three communicative classroom observations were carried out in IGs, one in each class. A communicative observation implies that the researcher beyond the commonly known observations shares the interpretation of the observed actions with the participants and again taking the scientific evidence into account. Therewith the conclusions of the observation are 
the result of a jointly constructed interpretation of the reality observed. Misinterpretations by the researcher can be clarified through the dialogue on the meaning of their actions.

To understand the contributions of IG in ECEC, we sought a comparative narrative by the participants highlighting the differences within the same school before and after the implementation of IG in ECEC. The communicative in-depth interviews, observations and daily-life stories, were aimed at assessing the cognitive development of the children as well as at collecting evidence of the children's social development between the two periods of time. The different techniques used make it possible to triangulate the information obtained and thus provide significant data of and insight into the reality of IG being implemented in the ECEC programme at Hope school and are interpreted appropriately (Bergman, 2008). If data collected in these techniques shows disagreements between the diverse profiles, incoherence between the observations and interviews or life stories, or misinterpretations by the researchers these are discussed with the participants to clarify their meaning. Therewith we can assure that data gathered corresponds with the reality analysed and that the statements made here with the quotations represent the general perception of the people involved in the reality being investigated.

At the time of the fieldwork the ECEC programme in Hope school counted with one class per year group due to the low number of children enrolled in each year group and in the whole ECEC programme. We opened up the participation to the people involved in the ECEC programme -children, teachers and volunteers who were family members- and finally interviewed all three teachers for the 3,4 and 5-year-olds, respectively, some of the volunteers and several of the 5 years old children. The profiles of the people involved in each of these techniques are summarised in Table 1. Every person involved participated voluntarily, and only after informed consent was obtained from parents, teachers and children for both the interviews and the observations. To protect their identities, the names used in the article both for the participants and for the school are pseudonyms. The interviews took place in the school building and generally lasted for about one hour, although in the case of the communicative daily-life stories with children, they were approximately 30-45 minutes. All interviews were tape recorded for the later analysis.

Table 1: Data collection techniques and participant profiles

\begin{tabular}{|c|c|c|c|}
\hline Techniques & No. & Pseudonym & Profile \\
\hline \multirow[t]{3}{*}{$\begin{array}{l}\text { Communicative in- } \\
\text { depth interview }\end{array}$} & 3 & Elisa & $\begin{array}{c}\text { Teacher in the } 3 \text {-year-old class. Teaching at } \\
\text { the school for } 6 \text { years }\end{array}$ \\
\hline & & Marta & $\begin{array}{l}\text { ESL (English as Second Language) teacher in } \\
\text { the } 3-\text {, 4- and } 5 \text {-year-old classes. Teaching at } \\
\text { the school for } 6 \text { years }\end{array}$ \\
\hline & & Teresa & $\begin{array}{c}\text { Teacher in the 4-year-old class. Teaching at } \\
\text { the school for } 3 \text { years }\end{array}$ \\
\hline \multirow{4}{*}{$\begin{array}{l}\text { Communicative daily- } \\
\text { life story }\end{array}$} & 6 & Raquel & Mother and volunteer in ECEC since 2010 \\
\hline & & Susana & $\begin{array}{l}\text { Roma mother and volunteer in ECEC since } \\
\qquad 2010\end{array}$ \\
\hline & & Noelia & 5-year-old girl \\
\hline & & Sergio & 5-year-old boy \\
\hline
\end{tabular}




\begin{tabular}{|c|c|c|c|}
\hline & & Mar & 5-year-old girl \\
\hline & & Lucia & 5-year-old girl \\
\hline \multirow{3}{*}{$\begin{array}{c}\text { Communicative } \\
\text { observation }\end{array}$} & \multirow[t]{3}{*}{3} & & 3-year-olds' classroom \\
\hline & & & 4-year-olds' classroom \\
\hline & & & 5-year-olds' classroom \\
\hline TOTAL & 12 & & \\
\hline
\end{tabular}

\subsection{Data analysis}

The data analysis was guided by the communicative methodology, which as already mentioned, has a transformative character -in this case, improving the reality of the individuals participating in the school. Therefore, the methodology distinguishes in the analysis between two distinctive dimensions -exclusionary and transformative-, between those elements that provide information on the barriers for social transformation and those elements that represent opportunities for overcoming these barriers. Under the INCLUD-ED project, in which the present analysis is framed, these dimensions were aimed at identifying those elements that provide information on the barriers that prevent people or collectives from having access to certain benefits (exclusionary dimension), and those components of reality that help in overcoming such barriers (transformative dimension). For this specific case study, the transformative dimension refers to the components of IGs that encourage the inclusion of the children from the neighbourhood in ECEC, promoting their cognitive, social and emotional development, while the exclusionary dimension refers to the components of IGs that prevent those benefits from occurring. The analysis, through communicative in-depth interviews, observations and daily-life stories, was aimed at assessing the cognitive development of the children as well as at collecting evidence of the children's social development between two periods of time, before and after the implementation of IGs.

In addition to the exclusionary and transformative dimensions two categories of analysis were used, which correspond to some of the essentials for high-quality and inclusive ECEC identified in the literature review. In this regard, particular attention is placed on the importance of interactions and especially those with adults such as family and community members and those among peers. For the purpose of the article, we analysed the data according to those elements that evidence the impact of IGs on academic results and on emotional and social development. The evidences on cognitive development refer to data that show the participants' perception of either a barrier to a proper cognitive development, or an improvement in the same direction. In a similar vein, the category of social and emotional development focuses on those elements that support or hinder children's progress in these terms. We analysed the transcriptions of the communicative daily life stories and communicative interviews as well as the notes of the communicative observations for meanings of sentences and interactions that could shed light on these dimensions and categories.

To provide an example of the categorisation of the evidence into the exclusionary and transformative dimensions and one of the two categories -social and emotional development, the following explanation by Teresa, an ECEC teacher, of the importance of adequately implementing IGs in order to obtain the expected results will be helpful. To the question whether she has noticed differences in the academic achievement of diverse generations, she explains how role of the adult volunteer in IGs, when misunderstood, shows no positive results. Yet, when children in middle school classes start participating as volunteers in IGs in ECEC 
following the principles of IGs, they suddenly show a social and emotional development related to their younger peers. Thus in the example provided we have evidence for both the exclusionary and transformative dimension and for the category of the social and emotional development.

\section{Do you think that these children who are in ECEC now will pass with a good level to elementary classes?}

Yes, with a very good level, a normalized level. (...)

\section{Have you noticed any differences to previous generations who have not done interactive groups and those who have done them? Does it show in their level?}

Yes very much. As I told you the groups in elementary and middle school have bad habits. (...) Especially the middle school teachers, who are less trained in learning communities. I understand that in their case it is more difficult to do interactive groups, they have more difficulty in doing well, because if they understand that the role of the volunteer is to know about the subject, how is that person supposed to know about physics or chemistry? It's like putting me as a reference, but I don't remember, and I don't have to know. Then, students were also more used to simply copying, to have as a volunteer teachers who would provide them with the solutions, and they have realised when they came down to ECEC, and saw that it is nothing alike. And that this was not IGs. (...) Due to the interactive groups with middle school students participating in ECEC a huge emotional bond (...) And for this trip to the sea, the middle school students have decided to join us, to go together [instead of on their own]. So imagine the empathy that interactive groups generate. (Teresa, teacher)

We can see in this excerpt that quality interactions as outlined in the literature review is crucial for the positive social and emotional development. If interactions with the volunteers in IGs do not promote solidarity among the students, but rather focus on the cognitive development, the result is that they have more difficulties achieving the goal of IGs. On the contrary, when the same students learn how IGs should be working and engage in this educational practice as volunteers they, as well as the younger children, develop greater social and emotional bonds. As this quotation refers to middle school students in relation to IGs in ECEC it only serves as an example of the categorisation of the information.

In line with the aim of social transformation set forth by the communicative methodology, in this article we shed light on those elements that characterise IGs in ECEC in Hope school and their potential for multiplying interactions to help overcoming these general barriers and make it possible for the children in ECEC at Hope school to thrive academically and personally. Accordingly, data presented in the results section focus on those elements that could shed light on the success of the implementation of IGs in ECEC. Thus, we were looking for evidencing the impact of IGs on academic results and on emotional and social development taking a comparative narrative of the experience before and after the implementation of IGs in ECEC in Hope school into account.

3.3. The case study: How IGs are implemented in ECEC in Hope school enhancing interactions in small mixed-ability groups facilitated by diverse adults 
The communicative observations and interviews revealed that the ECEC classes $(3,4$ and 5year-old children) start every morning with an assembly. Unlike typical assemblies where families are only the audience, in this school, they are participants in the discussion and decision-making. The teacher creates a dialogic space in which families, children and teachers prepare themselves for the learning activity which is about to begin. They explain and discuss the ground rules for developing IGs successfully, such as how they will be distributed, what the activities are about, how to help and support each other in the group and the role of the adult volunteers in class and how they can foster peer interactions. For the children, the assemblies are useful for establishing a routine that helps them to be autonomous in their learning process from a very early age. Marta teaches English as a second language to children aged 3, 4 and 5. She describes the dynamic of the IGs:

We do all of the routines in the assembly and explain the groups; what group $\mathrm{n}^{\mathrm{o}} 1 \mathrm{will}$ be doing, and group $n^{\circ} 2$ and group $n^{\circ} 3$. We give a sticker to each child to identify to which group he or she is assigned to and on which table [he or she has to be], and then everyone goes to the group to which they belong. And then, after the 10-15 minutes that each activity lasts, well, they rotate. (Marta, teacher)

The students know that they will first stay for some time (between 10-20 minutes in most cases) at one table with an adult who may be a family member or any other volunteer from the community. The main role of the volunteers is to ensure that everyone is focused on the task, learning and helping others and meeting the learning objective. Volunteers are expected to encourage children to help each other by playing and learning with numbers, letters, or stories or speaking in English. In addition, when volunteers are parents they become a positive role model for their children as well as for the other students. The activities are carefully designed to promote learning interactions according to the time available and the structure of IGs. They are in line with the learning curriculum for ECEC in Spain and focus particularly on instrumental learning, such as introduction to literacy, logical or mathematical skills as well as communicative skills. The communicative observations further revealed that these activities are usually developed in a playful way with games or manipulative tasks, rather than with books or index cards, which would be more frequently used at later years.

In the classrooms observed, the IGs are as heterogeneous as possible in terms of learning ability, gender, cultural background, and other factors to maximise learning opportunities. Volunteers are aware of the inclusive approach of this activity, which takes advantage of diversity to benefit every single child. Susana, a mother volunteering in an IG in Hope, explains as follows:

We try to put those who are performing better with those who have the lowest academic results, so that those who are worse can learn from those who are better. But they always learn from each other; what one doesn't know the other one does. They help each other mutually. (Susana, Roma mother)

In her words, Susana, a Roma woman with no education, explains what Vygotsky (1978) defined as a critical part of children's learning and development: the guidance provided by more capable peers. It is important to emphasise that IGs help the children involved; working in mixed ability groups, even more capable peers have the chance to improve their skills by helping and influencing each other towards higher levels of cognitive development. In addition, in Interactive Groups, children also benefit from Susana's guidance as she facilitates and encourages dialogic interactions, by, for example, telling those who finish first to help another 
child or encouraging them to ask and answer all the questions they have among each other, if they can. Therefore, teachers and volunteers foster a crucial element for promoting high-quality ECEC: the active engagement of the children in the whole learning process (Gonzalez, PollardDurodola, Simmons, Taylor, Davis, Fogarty, \& Simmons, 2014; Hall, Sylva, Sammons, Melhuish, Siraj-Blatchford, \& Taggart, 2013).

The teacher, responsible for the pedagogical practice, organises suitable tasks and guarantees that the adults are promoting learning interactions in each group. Elisa, who teaches 3-yearolds, highlights the importance of clearly explaining to these adults how to facilitate children's dialogue and interaction. They do not have to teach them. She provides examples to volunteers to guide their role in the IG: "Come on! Get up and help him/her!' or if you see that he/she will do the exercises for him/her say: 'No, don't do it for him/her! Well, try to explain how to do it"" (Elisa, teacher). Volunteers can then encourage an environment for rich interactions among the children in which each of them learns, responding also to the specific needs of each child to further their skills in the zone of proximal development. Furthermore, it evidences the importance of distinguishing between adult guidance and the interactions between more capable peers. The role of the adult in IGs is to promote positive interactions, thus focuses on values such as solidarity, taking care of the other, solving problems together, and asking others for help, while the interactions among children also include the cognitive aspects of explaining others how to solve problems.

An example of how children incorporate these enriching interactions is also given by Elisa. For instance, Elisa states that in maths children use the explanations given by her to help another student solve the problem, thus, multiplying dialogic and positive interactions among the children, which is further corroborated in the communicative observations.

In maths they are able to pose a problem to one another, to ask the other: 'well if you have... then is it more or less? What do you have to do if you receive? What do you have? More or less?' Then they say 'more'. 'So, if it is more, what do you have to do? Add or subtract?' They all imitated me in what I had explained before and then little by little they start using these resources themselves. (Elisa, teacher)

\section{RESULTS}

This section presents an analysis of the implementation of IGs in ECEC in Hope school from the perspective of the different participating collectives in this research: parents, teachers and children. We discuss the acceleration of the cognitive development and the promotion of positive social and emotional development.

\subsection{Perception of an acceleration of the cognitive development and high expectations}

One of the main results identified in the analysis is that the participants perceive an acceleration in cognitive development due to the multiplication of interactions in IGs. According to the teachers' interviews and the mothers' life stories, IGs seem to be effective in promoting interactions and dialogue among the children involved as they enhance reading acquisition and language development as well as mathematics and English as a second language.

While differentiation by ability could start at very early stages due to the wide range of ability levels existing in the same age group, IGs effectively prevent ability grouping, because 
according to this type of classroom organisation all children enrolled regardless of their ability levels, backgrounds, disabilities, and other diverse features are placed in heterogeneous groups. In IGs in ECEC in Hope school no child is taken out of the classroom, but they work together in heterogeneous groups. However, having students together in groups does not always lead to equal results. What makes IGs particularly successful is the fact that they are multiplying learning interactions among children and between children and adults, which accelerates the learning process and helps students obtain the required results. This is particularly important in this school since most of the children are Roma and come from highly marginalised families in which adult illiteracy rates are especially elevated.

The students' assessments and usual school evaluations reported on by the teachers confirm their perception of the acceleration of cognitive development through IGs in ECEC in Hope school. For example, Teresa, the teacher of a 4-year-old children's class, explains that in IGs the children complete more tasks than they do in other types of classroom organisation because less time is spent making the children focus on the activity: "In IGs, in just one hour, they are

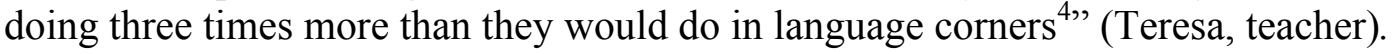

Also the children evidence their increased learning compared to previous generations of children in the same school. For instance Mar, a 5-year-old girl who, when asked about the English classes, started counting in English to explain the classroom dynamics and the contents they learn.

\section{And what do you do in the spider nets?}

There are holes and every spider has to climb it and... we have to throw the dice and if we have a 2 we do: One, two! And we talk in English.

Ok. And if you have a 6, what do you do?

I count to... one, two, three, four, five, six! (Mar, girl)

This excerpt was taken into account as the mere utterance and words pronounced in English by the 5-year-old girl already show her cognitive development. The context of the communicative daily life story did not require showing her cognitive skills, but these competencies are already interiorised and together with her pride and joy about her knowledge, she is happy to share this naturally with the researcher. Considering the situation of previous generations who remained almost illiterate even in their mother tongue at later ages, this behaviour is striking and can thus be categorised as evidence for the transformative dimension of IG in ECEC in the category of academic achievements.

The perceptions of the academic performance of children through teachers' assessments of the 5 -year-old children were that they were higher after the first three months of participation in IGs than before IGs were introduced, especially for reading and writing. The teachers point to some results being higher compared to other schools in the same region despite the social deprivation in this community. One of the teachers expresses her perception as an improvement in the school's assessment data, particularly in terms of reaching the level of other schools:

The assessment of the first three months has been so much higher, and it has reached normal levels that had not been reached [in the school] until now. In regard to other schools, for example, if I compare it to the assessments that I did in the schools where

\footnotetext{
${ }^{4}$ Language corners are spaces in the classroom where children can play autonomously with learning material for literacy in ECE, without the interaction of adults.
} 
I worked, (...) the contrast is, well, in some aspects the results are [in this school] even better than for those students [of other schools], especially their reading and writing skills. (Marta, teacher)

According to the teachers' observation of the children's learning development throughout the ECEC courses, IGs contribute particularly to consolidating reading proficiency. Elisa started implementing IGs in her class three years ago, and she emphasises the results obtained and the impact of this practice on children at the age of 5 :

What amazed me the most was the acceleration of learning (...) they were reading at 5. However, reading, not st-st-stick, no. Reading, (...) at the age of 5 they read perfectly. They took what you have here [a text with printed letters] even with italic letters, any kind of texts, calligraphy, anything. And all this was thanks to IGs at age 3. (Elisa, teacher)

The quote evidences the teacher's perception of children reversing their social and educational exclusion. Whereas many of the family members had no or only very low educational levels, and high illiteracy rates, Elisa tells us that children are able to read at the age of 5. The mothers also explain how the development of their children and the whole group has been accelerated since IGs were introduced. Raquel, a mother who volunteers, explains that in the beginning she thought that this type of grouping would benefit only those children without any difficulties. Later she perceived that all children made progress and that it contributed to reducing the achievement gap:

The first time I thought: this works with the smart ones (...) When the school year was over they were all the same. All the same [they all had learned the same]. That's why I'm saying this is great and they will equal up little by little. (Raquel, mother)

This indicates the perception that the implementation of IGs may contribute to breaking the link between socially disadvantaged children and educational failure. The families and teachers explain the differences in progress between children who participate in IGs from an early age and those who do not. Raquel experienced that difference in her own family. Her older sons attended preschool in the same school before the implementation of IGs. They still have difficulties with reading and writing, even in the third grade of primary education (age 8-9). Now, the difference is that her youngest child already recognises letters, sounds and words in more than one language: "My 9-year-old son didn't know how to read. Now my 3-year-old daughter already knows English [as a second language]" (Raquel, mother).

The improvement that Raquel saw between her older and younger children is not an isolated case; it has been a trend in the school since IGs were introduced. Susana, the Roma mother, relates a similar difference when talking about her children:

My 12-year-old boy, at the age of 5, as my daughter is, didn't know all the things that she knows now. There is a difference (...) The 10-year-old has done IGs since he was 6 , not before. And you can also see the difference to the girl (...) a big difference. (Susana, Roma mother)

Awareness of their own children's improvements seems to be a motivation for families to be involved in the school and to volunteer to help with children's learning in the classroom. This 
participation allows them to understand the benefits of having children work with diverse adults in mixed-ability groups, in which children are encouraged to challenge each other to learn together. By preventing children from being segregated based on ability at very early stages and by creating inclusive classrooms where high-quality education is provided for the children in ECEC in Hope school, the general perception is that they all are able to become school ready. Both the mothers and the teachers interviewed emphasise their perceptions that IGs lead to more successful transitions from preschool to primary school facilitated by reading skills that are more than appropriate for the children's age. Raquel and Susana, as mothers, have experienced how their youngest children have benefitted from participating in IGs during this transition:

It's true, if you start at the age of 3 you won't see the difference at all. Not at all. When they start primary education, they won't say 'This child is behind and this one is more advanced' because they will be equal. (Raquel, mother)

With regard to those in early childhood education, now they have it much easier [to pass to primary education] than the older ones [who did not participate in IGs in ECEC]. Yes, it's much better that they start in early years. (Susana, Roma mother)

The positive effects perceived by the participants that children experience from participating in IGs from early childhood have influenced the families' academic expectations. After many years of failure and exclusion, school had no meaning for families that were socially marginalised. However, their experience in IGs has restored their hope in education, and that might open the possibilities for a better future. Teresa, a teacher for the 4-year-olds, has observed this shift herself: "The expectations [of the families] are very high now; they have seen the difference, especially the families [whose children] have [older] brothers and sisters." According to the teachers and based on our observations, children are enthusiastic about working hard and learning. Marta, an ESL teacher, explains that feeling when talking about children's perceptions that "I can make it" and that "many of them want to become teachers like us" (Marta, teacher). Transforming families', children's and teachers' expectations has made a great difference in the school. It has enabled students and families of this school to dream of a better education and a better life. In 2007, children in the school had never heard about university; that word had no meaning for them. In 2013, Noelia and Mar, both 5 years old, had high expectations for themselves: they wanted to become "either a teacher or a doctor for little children... paediatric." (Noelia, girl). When Mar was asked why she wanted to become a teacher she said: "Because also I want to explain things to the children... the cards (...) and also, I want to be a teacher for the things in English (...) an English teacher (...) and a mother as well." (Mar, girl). When they were told that they would have to continue studying for many years, they replied: "Yes, I like that!" (Mar and Noelia, girls). This dialogue was once impossible in a context where, for so long, labelling and failure excluded children from education.

\subsection{Perception of the promotion of positive social and emotional development}

Given that high-quality ECEC should address cognitive, social and emotional development, our analysis of IGs also focused on the two latter spheres of development in the learning environment. However, these dimensions appeared to be related to the cognitive aspects and tightly linked to each other. Help and support were very much related to improving other children's learning and at the same time increasing positive interpersonal relationships. In 
addition, children as well as the teachers emphasise the well-being of children in school since IGs were implemented. Noelia illustrates these multiple aspects in her life story:

\section{And do you like them [the IGs]?}

Yes, because I want to help.

Who do you want to help?

All my mates.

\section{What for?}

So that they learn. (Noelia, 5-year-old)

When asked why he likes IGs, 5-year-old Sergio also indicates that he likes them because in IGs the children help each other:

\section{Why do you like IGs?}

Well, for example, if you do not know how to do some letters or if you cannot paint something, any of your mates helps you, so you know how to do it.

\section{And you also help others?}

Yes, I like to help them. I help my friend in mathematics, but it is she who has to practice, I just help her. (Sergio, 5-year-old)

According to Teresa the children in general enjoy participating in IGs and even states that parents end up taking their children to school because these ask for it: "once you have the child here (in IGs), it is the child who asks for coming to school. And the mother has no other choice than bringing him!" (Teresa, teacher). But as we can see in the excerpts of the life stories with Noelia and Sergio, they not only enjoy IGs, but they enjoy learning and helping others evidencing a positive social and emotional development.

In our observations of IGs, adults promoting interactions among peers is the common dynamic. As a result, the children understand and share an attitude of solidarity that becomes common in their daily life. Children there learn to develop supportive relationships and experience solidarity from an early age. This study's observations and interviews revealed that, in IGs, the perceived acceleration of learning has a positive influence on social development. Marta, the teacher, points to the fact that the children learn to pay attention to those who may have more difficulties and they offer help: "One child that is a little bit behind sees that in IGs he is doing the same as the rest. And there are even some children that are concerned about it [and say:] 'I will help you!"' (Marta, teacher).

The general perception that we draw from the fieldwork is that children participating in IGs from ECEC onwards develop much more empathy for their peers as well as being more attentive to another person's needs. Through the interactions with the adult volunteers they learn to look out for the other children and help them when they need it. The data points to the perception that if one child has more difficulty in solving a problem it is no longer seen as a deficit of that child but a problem for the whole group. The peers are asked to respond to this situation using their resources to help the child develop. We can thus see how the zone of proximal development described by Vygotsky (1978) receives much greater stimulation in this context than in other educational settings and especially in classrooms that are segregated by children's ability levels. According to the research participants, this solidarity and these supportive relationships seem to expand beyond the IGs and appear in other school spaces where friendship is promoted. Teresa and Susana explain the following: 
It improves how they coexist. As they learn to help each other in IGs, they then transfer it to other contexts: in the assemblies, on the playground, when mediating conflicts among mates. (Teresa, teacher)

It improves friendship greatly. They are much more united. They help each other more. They talk to each other, they mediate among one another. Interactive groups are everything. (For example before they would have said) 'I have done this puzzle before you did!' But not anymore, now they help each other and the group has done it, it wasn't 'me' neither 'you'. (Susana, Roma mother)

The interactions taking place in IGs through the use of language to solve the tasks that children are working on are reproduced in these other spaces. Children enrolled in ECEC at Hope and involved in IGs learn to use their resources to argument their position in any of the contexts mentioned by Teresa. As a result, it appears that emotional development is also reinforced. As Susana explains, children develop stronger ties among each other, which results in greater selfconfidence to express one's needs and to try to help a friend meet these needs. Self-esteem and motivation are essential in the process of development for all children, but they are particularly important for children from deprived contexts so that their learning and their life can still be successful. Another aspect that was observed and that emerged in the interviews with mothers, teachers and children is that the enthusiasm for IGs is also transferred to their general attitudes towards learning. Elisa and Marta express it as follows:

(...) the emotional development, because, especially here, so that all the children work well, they need to be motivated, to push their self-esteem (...) They are much more motivated there (in IGs), but this motivation is not lost in other places. Now they are enthusiastic about learning (Elisa, teacher).

Something that motivates you is something that leaves a mark for the rest of your life. (Marta, teacher)

Both teachers emphasise the deep feelings of motivation and enthusiasm that their pupils develop and internalise while working in Interactive Groups. The general perception here is that students in ECEC in Hope school are studying and learning, while at the same time socialising in a motivational environment that makes a positive difference in their lives. Contrary to previous generations at the same school, where children used to drop out even before completing primary education, the fieldwork conducted for this study shows that participants perceive that children involved in IGs in ECEC are enthusiastic about learning and demonstrate this enthusiasm with an increased cognitive, social and emotional development.

\section{DISCUSSION AND CONCLUSION}

This study shows that the families, teachers and pupils of the ECEC programme at Hope, an urban school that implemented IGs in ECEC agree that, since IGs were introduced as part of the school's pedagogical practices in early childhood education, children have gained academic skills in different competencies while at the same time they have increased their engagement and improved their social relationships. By leveraging language as a cultural and psychological tool (Vygotsky, 1962) for children's development, IGs promote interactions in mixed-ability groups and are perceived to be an effective response to the challenge of early classroom leaving by transforming the classroom into a complex, heterogeneous, rich and stimulating learning environment. Instead of segregating children by their ability or ethnic background they participate in the classroom activities and are requested to interact with and help their peers if 
they can. The engagement of adult volunteers in each of the interactive groups helps promote positive peer interactions, as they encourage children to ask for or offer help to their more or less capable peers respectively. The opportunities for interactions that stimulate the zone of proximal development thus increase and help these children transform those skills that are less developed into consolidated knowledge. The explanations given by the research participants on their experience with the implementation of IG in early childhood education in Hope school underline that these skills can be very diverse and refer to cognitive skills but also to social and emotional development. For each of these dimensions we found that the general perception of the research participants is that IGs promote positive results in academic performance and in the children's social attitudes with other children and their general emotional well-being.

In this regard, the participants express their appreciation of improvements of the cognitive development. For instance, the teachers and mothers emphasise that children who started IGs during ECEC achieved greater reading levels than those who started IGs in later years preparing them for being school ready to smoothly transition to primary education. They emphasise that suddenly in a school, where school failure and dropout rates were standard, now they see similar, or even greater reading skills than their peers in other schools. In a similar vein the life stories with 5-year-old children revealed in a very natural way their English skills. While explaining the classroom dynamics in English classes they started counting in English.

The analysis shows the importance of IG in promoting a context in which children who need more attention and support to understand or assimilate certain knowledge can express their situation and find support in their peers. The teachers in the case study created the space for acknowledging difficulties and for receiving support, which was enhanced by the volunteers. Since children have many different zones of proximal development according to the skill contemplated, the case study shows that the children participating in IGs in Hope School find the optimal space to have interactions that help them develop.

Concerning the social and emotional development the fieldwork in this case study evidenced that teachers, mothers and children agree on their perception of improved social and emotional attitudes. Whereas the teachers and mothers interviewed emphasise that children care more about their peers, the children state that they enjoy helping each other while appreciating others helping them as well. Mothers and teachers perceive the positive social attitude as a result from implementing IGs in ECEC and the fact of encouraging children to look after each other and help those who need it and let themselves be helped.

This analysis of Interactive Groups shows that teachers, mothers and children perceive that this classroom practice promotes cognitive, emotional and social development. Some of the key factors that emerged from the observations, interviews with teachers and daily-life stories with mothers and children were: (a) the multiplication of dialogic interactions as a result of organising mixed-ability groups facilitated by family members and diverse adults; and (b) the perception of accelerated learning and cognitive skills (i.e., reading) through mutual help and peer support which promote social and emotional development at the same time. The results obtained, though limited in their scope, are important as the positive effects perceived by the research participants involves people belonging to some of the most disadvantaged groups, such as Roma, and this practice seems to the eyes of the research participants to be helping to prevent their educational exclusion from an early age.

Finally, we acknowledge the limitations of this study. Although we accounted for data triangulation in our sample by analysing several sources of information, the findings stem from 
a single case study in a particular context. To address this limitation, the study could be replicated in other schools that are implementing IGs in ECEC. In addition, case studies with a longitudinal perspective (including quantitative and statistical analyses) could contribute evidence of the effectiveness of this intervention and its influence on schooling at later stages. More systematic results analysis can also help to track the outcomes of the intervention, or similar interventions. Moreover, conducting in-depth analysis of the debates and discussions that take place in each Interactive Group would provide more detailed information about why those dialogic interactions have benefited children in this school, as well as how this particular classroom organisation can open the door to a better education and a better future.

\section{REFERENCES}

Abenavoli, R. M., Greenberg, M. T., \& Bierman, K. L. (2015). Parent support for learning at school entry: Benefits for aggressive children in high-risk urban contexts. Early Childhood Research Quarterly, 31,9-18. doi:10.1016/j.ecresq.2014.12.003

Bae, B. (2009). Children's right to participate - challenges in everyday interactions. European Early Childhood Education Research Journal, 17(3), 391-406. doi: 10.1080/13502930903101594

Beck, U. (1992). Risk society: Towards a new modernity. London, UK: SAGE.

Belfield C. R., \& Levin, H. (2007). The price we pay. Economic and social consequences of inadequate education. New York: Brookings.

Bennett, J. (2011). Introduction: Early Childhood Education and Care, Encyclopedia on Early Childhood Development, Centre of Excellence for Early Childhood Development and Strategic Knowledge Cluster on Early Child Development, Montreal. Retrieved from www.child-encyclopedia.com/pages/PDF/BennettANGxp1-Intro.pdf

Bergman, M. M. (2008). 2 troubles with triangulation. In Advances in mixed methods research (pp. 22-36). SAGE Publications Ltd. doi: 10.4135/9780857024329.d4

Boaler, J., Wiliam, D., \& Brown, M. (2000). Students' experiences of ability grouping disaffection, polarisation and the construction of failure. British Educational Research Journal, 26(5), 631-648. doi:10.1080/713651583

Bodovsky, K., \& Youn, M. (2012). Students' mathematics learning from kindergarten through $8^{\text {th }}$ grade: The Long Term Influence of School Readiness. International Journal of Sociology of Education, 1(2), 97-122. doi:10.4471/rise.2012.07

Braddock, J. H., \& Slavin, R. E. (1992). Why ability grouping must end: achieving excellence and equity in American Education. Center for Research on Effective Schooling for Disadvantaged Students, Baltimore, Sep 92. Paper presented at the Common Destiny Conference at Johns Hopkins University (Baltimore, MD, September 9-11, 1992). Retrieved from eric.ed.gov/?id=ED355296

Brown, M., Gómez, A., \& Munté, A. (2013). Procesos dialógicos de planificación de los servicios sociales: el proceso de cambio en los barrios de La Milagrosa y La Estrella (Albacete). Scripta Nova: Revista Electrónica de Geografia y Ciencias Sociales, 17 (277).

Carr, M., Barned, N., \& Otumfuor, B. (2016). Peers Influence Mathematics Strategy Use in Early Elementary School. International Journal of Educational Psychology, 5(1), 27-55. doi: 10.17583/ijep.2016.1861

Chorzempa, B. F., \& Graham, S. (2006). Primary-grade teachers' use of within-class ability grouping in reading. Journal of Educational Psychology, 98(3), 529-541. doi:10.1037/0022-0663.98.3.529 
Cooper, C. E. (2010). Family poverty, school-based parental involvement, and policy-focused protective factors in kindergarten. Early Childhood Research Quarterly, 25(4), 480-492. doi:10.1016/j.ecresq.2010.03.005

Cunha, F. J., Heckman, J., Lochner, L., \& Masterov, D. V. (2005). Interpreting the evidence of life-cycle skills formation. IZA Discussion Papers, No. 1575. Bonn: Institute for the Study of Labour.

Danby, S., Thompson, C., Theobald, M., \& Thorpe, K. (2012). Children's Strategies for Making Friends when Starting School. Australasian Journal of Early Childhood, 37(2), 63-71. Retrieved from eprints.qut.edu.au/46445/

Denham, S. S., Bassett, H., Mincic, M., Kalb, S., Way, E., Wyatt, T., \& Segal, Y. (2012). Social-emotional learning profiles of preschoolers' early school success: A personcentered approach. Learning and Individual Differences, 22(2), 178-189. doi:10.1016/j.lindif.2011.05.001

Díez-Palomar, J., Santos-Pitanga, T., \& Álvarez-Cifuentes, P. (2013). La Paz School: From a Ghetto to a Magnet School. International Review of Qualitative Research, 6(2), 198-209. doi.org/10.1525/irqr.2013.6.2.198

Elboj, C. (2015). Clara, From the Ghetto to the European Parliament. Qualitative Inquiry, 21(10), 879-885. doi:10.1177/1077800415611695.

Elffers, L. (2012). One foot out the school door? Interpreting the risk for dropout upon the transition to post-secondary vocational education. British Journal of Sociology of Education, 33(1), 41-61. doi: 10.1080/01425692.2012.632866

Elster, J. (1998). Deliberative democracy. Cambridge, UK: Cambridge University Press.

Engevik, L. I., Hølland, S., \& Hagtvet, B. H. (2015). Re-conceptualizing "directiveness" in educational dialogues: Acontrastive study of interactions in preschool and special education. Early Childhood Research Quarterly, 30, 140-151, doi:10.1016/j.ecresq.2014.10.004

European Commission. (2010). Science Against Poverty Conference. La Granja, Spain. April 2010. Retrieved from www.scienceagainstpoverty.es

European Commission. (2011a). Communication from the Commission. Early childhood education and care: providing all our children with the best start for the world of tomorrow. $\operatorname{COM}(2011) 66$ final. Brussels: European Commission. Retrieved from http://europa.eu/legislation_summaries/education_training_youth/lifelong_learning/ef0 027 en.htm

European Commission. (2011b). Communication from the Commission to the European Parliament, The Council, The European Economic and Social Committee and The Committee of the Regions. Tackling early school leaving: a key contribution to the Europe 2020 Agenda. COM(2011) 18 final. Brussels: European Commission. Retrieved from

http://europa.eu/legislation_summaries/education_training_youth/lifelong_learning/ef0 026 en.htm

Eurydice. (2009). Tackling Social and Cultural Inequalities through Early Childhood Education and Care in Europe, Eurydice. Education. Audiovisual and Culture Executive Agency. European Commission, Brussels. Online ISBN 978-92-9201-007-2. doi: $10.2797 / 18055$

Flecha, R. (2015). Successful Educational Actions for Inclusion and Social Cohesion in Europe. Springer Publishing Company. Online ISBN 78-3-319-11176-6.

Flecha, R., Soler, M., \& Sordé, T. (2015). Social impact: Europe must fund social sciences. Nature, 528, 193. doi:10.1038/528193d 
Flecha, R., \& Soler, M. (2013). Turning difficulties into possibilities: engaging Roma families and students in school through dialogic learning. Cambridge Journal of Education, 43(4), 451-465. doi:10.1080/0305764X.2013.819068

Fram, M. S., Kim, J., \& Sinha, S. (2012). Early Care and Prekindergarten care as influences on school readiness. Journal of Family Issues, 33(4), 478-505. doi:10.1177/0192513X11415354

Galindo, C., \& Sheldon, S. B. (2012). School and home connections and children's kindergarten achievement gains: the mediating role of family involvement. Early Childhood Research Quarterly, 27(1), 90-103. doi:10.1016/j.ecresq.2011.05.004

García, R., Girbés, S., \& Gómez, G. (2015). Promoting Children's Academic Performance and Social Inclusion in Marginalized Settings: Family and Community Participation in Interactive Groups and Dialogic Literary Gatherings. In L.D. Hill.; F. J. Levine. World Education Research Yearbook 2015. New York: Routledge. ISBN-13: 978-1138797123

García-Carrión, R. \& Villardón-Gallego, L. (2016). Dialogue and Interaction in Early Childhood Education: A Systematic Review. Multidisciplinary Journal of Educational Research, 6(1), 51- 76. doi:10.17583/remie.2016.1919

Garcia-Yeste, C., Redondo-Sama, G., Padrós, M, \& Melgar, P. (2016). The Modern School of Francisco Ferrer i Guàrdia (1859-1909), an International and Current Figure. Teachers College Record, 118(4), 1-36.

Gatt, S., Ojala, M., \& Soler, M. (2011). Promoting social inclusion counting with everyone: Learning Communities and INCLUD-ED. International Studies in Sociology of Education, 21(1), 37-47. Retrieved from www.tandfonline.com/doi/abs/10.1080/09620214.2011.543851\#.VZv0o_ntlBc

Giddens, A. (1991). Modernity and self-identity: Self and society in the late modern age. Cambridge, UK: Polity.

Girbés-Peco, S., Macías-Aranda, F., \& Álvarez-Cifuentes, P. (2015). De la Escuela Gueto a una Comunidad de Aprendizaje: Un Estudio de Caso sobre la Superación de la Pobreza a Través de una Educación de Éxito. International and Multidisciplinary Journal of Social Sciences, 4(1), 88-116. doi: http://dx.doi.org/10.17583/rimcis.2015.1470

Gómez, A., Puigvert, L., \& Flecha, R. (2011). Critical Communicative Methodology: Informing Real Social Transformation through Research. Qualitative Inquiry, 17(3), 235-245. doi.org/10.1177/1077800410397802

Gonzalez, J. E., Pollard-Durodola, S., Simmons, D. C., Taylor, A. B., Davis, M. J., Fogarty, M., \& Simmons, L. (2014). Enhancing preschool children's vocabulary: Effects of teacher talk before, during and after shared reading. Early Childhood Research Quarterly, 29(2), 214-226. doi: 10.1016/j.ecresq.2013.11.001

Graves, S. (2011). School and child level predictors of academic success for African American children in third grade: implications for No Child Left Behind. Race, Ethnicity and Education, 14(5), 675-697. doi:10.1080/13613324.2010.547849

Habermas, J. (1987). The theory of communicative action. V. 2. Lifeworld and system: A critique of functionalist reason. Boston, MA: Beacon Press.

Hall, J., Sylva, K., Sammons, P., Melhuish, E., Siraj-Blatchford, I., \& Taggart, B. (2013). Can preschool protect young children's cognitive and social development? Variation by center quality and duration of attendance. School Effectiveness and School Improvement: An International Journal of Research, Policy and Practice, 24(2), 155-176. doi:10.1080/09243453.2012.749793

Hallam, S., Ireson, J., \& Davies, J. (2004). Primary pupils' experiences of different types of grouping in school. British Educational Research Journal, 30(4), 515-533. doi:10.1080/0141192042000237211 
Hallam, S., \& Parsons, S. (2013). The incidence and make up of ability grouped sets in the UK primary school. Research Papers in Education, 28(4), 393-420. doi: 10.1080/02671522.2012.729079

Hartup, W. (1996). The company they keep: friendships and their developmental significance, Child Development, 67(1), 1-13. doi:10.2307/1131681

Hedegaard, M. (2014). The significance of demands and motives across practices in children's learning and development: An analysis of learning in home and school. Learning, Culture and Social Interaction, 3(3), 188-194. doi:10.1016/j.lcsi.2014.02.008

Howe, C., \& Abedin, M. (2013) Classroom dialogue: a systematic review across four decades of research. Cambridge Journal of Education, 43(3), 325-356. doi:10.1080/0305764X.2013.786024

Huntsinger, C. S., \& Jose, P. E. (2009). Parental involvement in children's schooling: Different meanings in different cultures. Early Childhood Research Quarterly, 24(4), 398-410. doi:10.1016/j.ecresq.2009.07.006

Ireson, J., Hallam, S., \& Hurley, C. (2005). What are the effects of ability grouping on GCSE attainment? British Educational Research Journal, 31(4), 443-458. doi:10.1080/01411920500148663

Ishimine, K., \& Tayler, C. (2014) Assessing Quality in Early Childhood Education and Care, European Journal of Education, 49(2), 272-290. doi:10.1111/ejed.12043

Ladd, H. F. (2012). Education and Poverty: Confronting the Evidence. Journal of Policy Analysis and Management, 31(2), 203-227. doi:10.1002/pam.21615

Levin, H. (2009). The Economic payoff to investing in educational justice. Educational Researcher, 38(1), 5-20. doi:10.3102/0013189X08331192

Meacham, S. (2016). Peer relationships and internally persuasive discourse. Learning, Culture and Social Interaction, 9, 95-104. doi:10.1016/j.lcsi.2016.02.004

Mercer, N. (2008). The seeds of time: why classroom dialogue needs a temporal analysis. The Journal of the Learning Sciences, 17(1), 33-59. doi:10.1080/10508400701793182

Morlà Folch, T. (2015). Learning Communities, a dream that over 35 years ago that transforms Realities. Social and Education History, 4(2), 137-162. doi:http://dx.doi.org/10.17583/hse.2015.1459

OECD. (2011). Starting Strong III: A Quality Toolbox for Early Childhood Education and Care, OECD Publishing, Paris. doi: http://dx.doi.org/10.1787/9789264123564-en

OECD. (2012). Equity and Quality in Education: Supporting Disadvantaged Students and Schools. Paris: OECD. Retrieved from www.oecd.org/edu/school/50293148.pdf

Padrós, M. (2014). A transformative approach to prevent peer violence in schools: contributions from communicative research methods. Qualitative Inquiry, 7(20), 916922. doi:10.1177/1077800414537217

Pakarinen, E., Kiuru, N., Lerkkanen, M. K., Poikkeus, A. M., Ahonen, T., \& Nurmi, J. E. (2011). Instructional support predicts children's task avoidance in kindergarten. Early Childhood Research Quarterly, 26, 376-386. doi:10.1016/j.ecresq.2010.11.003

Piasta, S. B., Justice, L. M., Cabell, S. Q., Wiggins, A. K., Turnbull, K. P., \& Curenton, S. M. (2012). Impact of Professional Development on Preschool Teachers' Conversational Responsivity and Children's Linguistic Productivity and Complexity. Early Childhood Research Quarterly, 27(3), 387- 400. doi:10.1016/j.ecresq.2010.11.003

Popp, T., \& Wilcox, M. J. (2012). Capturing the complexity of parent-provider relationships in early intervention: the association with maternal responsivity and children's socialemotional development. Infants and young children, 25(3), 213-231. doi:10.1097/IYC.0b013e318258c63a 
Radziszewska, B., \& Rogoff, B. (1991). Children's guided participation in planning imaginary errands with skilled adult or peer partners. Developmental Psychology, 27(3), 381-389. doi:10.1037/0012-1649.27.3.381

Rhoades, B., Warren, H. K., Domitrovich, C. E., \& Greenberg, M.T. (2011). Examining the link between preschool social-emotional competence and first grade academic achievement: the role of attention skills. Early Childhood Research Quarterly, 26(2), 182-191. doi:10.1016/j.ecresq.2010.07.003

Roma Education Fund (2015). Annual Report 2014. Hungary: Roma Education Fund. Retrieved from www.romaeducationfund.hu/sites/default/files/publications/ref_annual_2014_web_sing lepages-mod.pdf

Sairanen, H., \& Kumpulainen, K. (2014). A visual narrative inquiry into children's sense of agency in preschool and first grade. International Journal of Educational Psychology, 3(2), 141-174. doi:10.4471/ijep.2014.09

Sammons, P., Sylva, K., Melhuish, E. C., Siraj-Blatchford, I., Taggart, B., \& Grabbe, Y. (2007). Effective Pre-school and Primary Education 3-11 Project (EPPE 3-11): Influences on Children's Attainment and Progress in Key Stage 2: Cognitive Outcomes in Year 5. Full Report. London: DfES/Institute of Education, University of London.

Schulz, M. S. (2016). Debating futures: Global trends, alternative visions, and public discourse. International Sociology, 31(1), 3-20. doi: 10.1177/0268580915612941

Stipek, D. (2006). No child left behind comes to preschool. Elementary School Journal, 106(5), 455-465. Retrieved from www.jstor.org/stable/10.1086/505440

Taguma, M., Litjens, I., \& Makowiecki, K. (2012). Quality Matters in Early Childhood Education and Care: Czech Republic, OECD. ISBN 978-92-64-17651-5 Retrieved from www.oecd.org/edu/school/50165788.pdf

Urban, M., Vandenbroeck, M., Van Laere, K., Lazzari, A., \& Peeters, J. (2012). Towards Competent Systems in Early Childhood Education and Care. Implications for Policy and Practice. European Journal of Education, 47(4), 508-526. doi:10.1111/ejed.12010

Valls, R., \& Kyriakides, L. (2013). The power of interactive groups: how diversity of adults volunteering in classroom groups can promote inclusion and success for children of vulnerable minority ethnic populations. Cambridge Journal of Education, 43(1), 17-33. doi.org/10.1080/0305764X.2012.749213

Vygotsky, L. (1962). Thought and Language. Cambridge MA: MIT Press

Vygotsky, L. (1978). Mind in Society: The Development of Higher Psychological Processes. Cambridge, MA: Harvard University Press.

Welsh, M., Parke, R. D., Widaman, K., \& O'neil, R. (2001). Linkages between children's social and academic competence: a longitudinal analysis. Journal of School Psychology, 39(6), 463-482. doi:10.1016/S0022-4405(01)00084-X

Whitebread, D. (2012). Developmental Psychology and Early Childhood Education. A Guide for Students and Practitioners. London: SAGE.

Wößmann, L., \& Schüetz, G. (2006). Efficiency and Equity in European Education and Training Systems. Analytical Report No. 1 Prepared for the European Commission. European Expert Network on Economics of Education (EENEE). Brussels: European Commission.

Zigler, E., Gilliam, W. S., \& Jones, S. M. (2006). A vision for universal preschool education. New York: Cambridge University Press. 